\title{
Determinants of business value increase
}

\author{
Aleksandr Loginov*, and Nikolay Maltsev \\ Ural State Mining University, 620144, Kuibyshev st., 30, Ekaterinburg, Russia
}

\begin{abstract}
The study is focused on identification of the main indicators promoting increase of business value by way of decomposition of value drivers, depending on used approach to the assessment. The authors analyzed the most common approaches to assessment of business value, identified and generalized the main factors with consideration of indigenous specifics, generated a list of primary indicators of company's business activities impacting increase of the business value.
\end{abstract}

One of the key subjects in focus of contemporary studies is an issue of designing the best and most effective business management system [2,4]. Unlike traditional systems and indicators, alternative approach was offered in terms of Value-Based Management (VBM) concept, which is based on approach that maximizes creation of value of owners and providers of capital.

In spite of promising outlook of this concept, the management often faces the following challenges in practice: diversity of conceptual VBM models, significant cost, and, consequently, unavailability of services of consulting companies developing value-focused management system to most of the small and medium sized enterprises.

This article summarizes results of conducted research, whose objective was identification of internal corporate factors effecting increase of business value, depending on approach used for the assessment. The achieved results are universal and adjustable to enterprises of any scale to the effect of further decomposition to medium and lower management level indicators (regulations, instructions, process charts etc.)

As of today, three traditional approaches to assessment are identified in terms of valuation activities regardless of class of assets: cost-based, comparative, and income approach.

Bearing in mind that the enterprises with signs of bankruptcy do not face any issues of identification of factors increasing the business value, the only acceptable approach to assessment of business value in terms of cost-based approach is net assets method. In general, calculation formula is provided below:

$$
\mathrm{C} K=\mathrm{A}-\mathrm{O}
$$

where $\mathrm{CK}$ - the business value for owners (equity capital);

A - total assets of the company;

$\mathrm{O}$ - total obligations of the company.

To identify the key factors effecting increase of net assets indicator, let us look at one contemporary technique for valuation of companies, known as Edward Bell Ohlson (EBO)

\footnotetext{
* Corresponding author: loginov_appraise@mail.ru
} 
model. Let us highlight the bottom line without getting down to details, advantages and disadvantages of this model: the model is based on so-called net increase ratio, which determines dynamics of net assets [7]:

where NA - net assets by end of the period (n, n-1);

$$
N A_{n-1}=N A_{n}+D_{n}-N P_{n}
$$

$\mathrm{NP}$ - net profit for the period n;

Dn - difference between dividends and any other payments from net profit and external loans, increasing net assets of the company (installments of shareholders to equity etc.).

It follows from equation 2 that increase of net assets of the company is directly affected by net profit value, number of dividends and other payments from net profit, and availability and amount of outward investments from owners/shareholder. Unlike the net value indicator (Figure 1), two last indicators are final and not subject to any further decomposition.

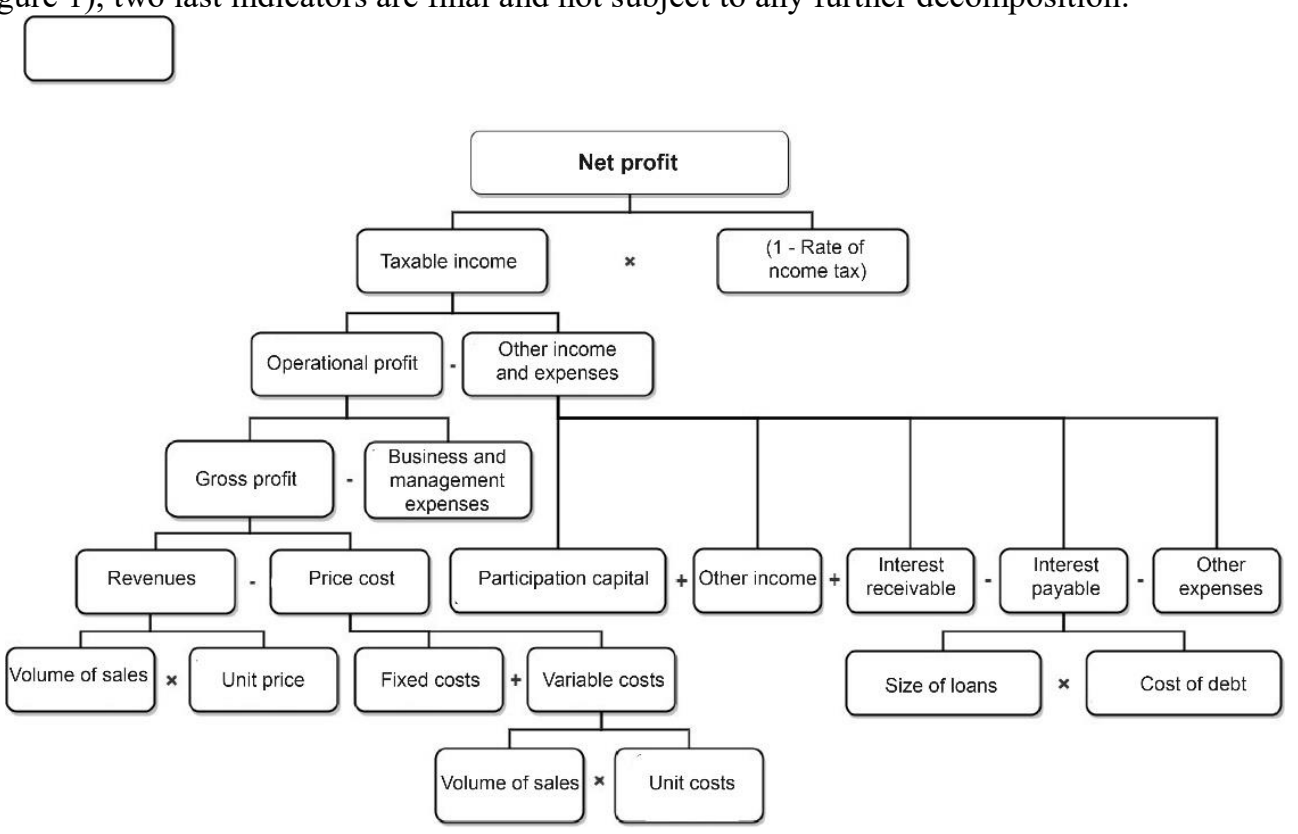

Fig. 1. Decomposition of net profit indicator

The factors, impacting the business value as per net assets approach in terms of cost-based method, are presented in the Table 1.

In terms of comparative approach to assessment, the business value is determined on the basis of market quotations of shares of the assessed company (for tradeable securities) or by alternative methods using multipliers, including the following ones, most commonly used in practice: cost / income, cost / cash flow, cost / dividends, cost / balance sheet value, cost / revenues, cost / production volume.

The value is calculated by multiplication of multiplier by appropriate indicator of the assessed business. In this case the numerator of the multiplier contains data related to market prices of comparable assets (similar enterprises), which the management has no effect on, unlike the denominator of the multiplier, containing the final indicators or indicators of business activities subjected to further decomposition.

Depending on class of income used in denominator of the cost/income multiplier, different factor models can be designed, while the most comprehensive among those is decomposition of net profit indicator (Ошибка! Источник ссылки не найден.). If the multipliers Cost / Net profit, Cost / profit on sales are used, influence of some factors is eliminated. 
The cash flow per equity capital or the whole invested capital can be used in denominator of the cost/cash flow multiplier, whose construction is generally based on net profit indicator, and increase of required own working capital is a difference between change of current circulating assets and current liabilities of the company.

The final indicators effecting the business value are used in denominator of the cost/dividends and cost/production volume multipliers. The cost factors for cost/revenues, cost/balance sheet value multipliers are determined at decomposition of net profit indicator in terms of net assets approach.

The main methods in terms of this approach are capitalization of income, wherein the cash flow or net profit indicators are converted into business value, while the cost factors for them were identified above.

Let's look at fundamental cost factors of economic models of business value management strategy in addition to traditional approaches to assessment of business value.

The main VBM models and indicators can be provisionally divided in three groups [1]:

1) Indicators based on accounting valuations (EVA, MVA, RI);

2) Indicators based on cash flows (CFROI, SVA, CVA);

3) Indicators based on market-based valuation (TSR, TBR).

The economic value added (EVA $\left.{ }^{\circledR}\right)$ was developed and registered by G. B. Stewart in 1991. According to this approach, the business value is increased with constant positive value of the EVA, and the negative EVA indicates reduction of the company value.

The economic value added of a firm is calculated according to the following formula:

$$
\mathrm{EVA}=\text { NOPAT }- \text { IC } \times \text { WACC }
$$

where EVA is the economic value added created by the net capital invested into the company; WACC is the weighted average cost of capital invested into the company;

IC is the capital invested into the company (value of company's assets);

NOPAT is the net operating profit after taxation of operative business.

In general, the weighted average cost of capital (WACC) raised for business can be calculated with the following formula [3]:

$$
\text { WACC }=\sum\left(\mathrm{W}_{\mathrm{e}} \times \mathrm{C}_{\mathrm{e}}\right)+(1-\mathrm{T}) \times \sum\left(\mathrm{W}_{\mathrm{d}} \times \mathrm{C}_{\mathrm{d}}\right)
$$

where We is the total shareholder's equity;

$\mathrm{Wd}$ is the total debt;

$\mathrm{Ce}$ is the cost of equity (in \%);

$\mathrm{Cd}$ is the cost of debt (in \%);

$\mathrm{T}$ is a corporate tax rate.

In furtherance of formulas (3) and (4), the key factors impacting EVA are received by way of decomposition of (NOPAT, IC, WACC) (Table 1).

Alternative indicator of increase of company value (particular case of EVA) is "Market Value Added" (MVA) indicator presenting discounted value of all current and future investments. It can be calculated with the following formula:

$$
\mathrm{MVA}=\mathrm{D}+\mathrm{M}-\mathrm{E}
$$

where $\mathrm{D}$ is the market cost of debt;

$\mathrm{M}$ is the market capitalization;

$\mathrm{E}$ is the total capital.

The MVA has a strong connection with market capitalization, therefore, taking into consideration immaturity of the Russian equity market, a decision was made not to use this model for identification of determinants of increase of the companies' value. The group of indicators based on market-value appraisal like "total share return" (TSR) and its version "total business return" (TBR) was not considered for the same reason.

The residual income (RI) model is the original one, historically. It is also known as EBO, based on names of economists that made major input in development of this model (EdwardsBell-Ohlson). According to this model, the business value is determined by current assets 
and super profits, but unlike the EVA, it uses the total of balance sheet value of equity and present value of super-profit generated by it as equity value.

This indicator can be calculated with the following formula:

where: NI is net profit;

$$
\mathrm{RI}=\mathrm{NI}-\mathrm{BVE} \times \mathrm{R}_{\mathrm{e}}=\left(\mathrm{ROE}-\mathrm{R}_{\mathrm{e}}\right) \times \mathrm{BVE}
$$

BVE is the balance value of equity capital;

Re is the equity value;

$\mathrm{ROE}$ is the return on equity (ROE).

Increase of the business value is generated owing to positive value of spread between the return on equity (ROE) and the equity value (Re). Generally, the ROE can be calculated with the following formula:

where: NI is net profit;

$$
\mathrm{ROE}=\frac{\mathrm{NI}}{\mathrm{E}}
$$

$\mathrm{E}$ is the equity capital.

Using the Du Pont formula, the return on equity can be calculated the following way:

where: NS is the revenues;

$$
\mathrm{ROE}=\frac{\mathrm{NI}}{\mathrm{NS}} \times \frac{\mathrm{NS}}{\mathrm{TA}} \times \frac{\mathrm{TA}}{\mathrm{E}}=\mathrm{NPM} \times \mathrm{TAT} \times \mathrm{FL}
$$

TA is total assets;

NPM is the net margin;

TAT is the total assets turnover;

FL is a financial lever.

Based on the formulas (7) and (8) a twelve-factors based ROE analysis can be presented [5]. Bearing in mind that most of the factors effecting the return on equity were studied earlier at decomposition of the net profit indicator and economic value added, the resulting factors impacting business value in terms of residual income model are listed in the Table 1.

The shareholders' value added (SVA) developed by Alfred Rappaport represents capitalized change of current value of cash flow from operations (CFO) adjusted by current value of investments in non-circulating and circulating capitals that caused such changes. “The shareholders' value added (positive value of SVA) is generated as soon as return on invested capital of the company exceeds the weighted average cost of capital (ROIC $>$ WACC)" [5].

A. Rappaport identified some factors that can be managed in order to increase the business value [8]:

1) revenues (increase of sales revenue, unit prices, incl. by maximizing the competitive advantage period);

2) operational profit (decomposition of factors is the same as for EVA);

3) rate of income tax;

4) value of investment in current capital;

5) value of investment in equity;

6) value of the weighted average cost of capital, WACC (decomposition of factors is the same as for EVA).

Return on investment (CFROI) is, in fact, a modified indicator of internal rate of return (IRR), but unlike IRR applied to capital investments already made, it is calculated like this:

where: CashIn is cash inflows adjusted for inflation;

$$
\text { CFROI }=\frac{\text { CashIn }}{\text { CashOut }}
$$

CashOut is cash outflows adjusted for inflation.

The Cash Value Added (CVA) indicator was developed by experts of BCG consulting company in 1996 and indicates the value of free cash flows to equity generated by investments in the company. Often times, it is calculated as Residual Cash Flow (RCF):

$$
\mathrm{CVA}=\mathrm{AOCF}-\mathrm{WACC} \times \mathrm{TA}
$$


where: TA is net assets evaluated as per original cost;

WACC is the weighted average cost of capital;

AOCF is adjusted cash flow from operations (accounting depreciation is replaced by economic depreciation, which is "determined as equivalent annual flow of allocations that returns the original cost of assets by the end of their useful life, while being invested in alternative investments at the rate of weighted average cost of capital" [1].

Table 1 summarizes the combination of factors effecting the business value, depending on methods and approaches applied to assessmentTable 1. Main factors of business value depending on .

Table 1. Main factors of business value depending on assessment methods

\begin{tabular}{|c|c|c|c|c|c|c|c|c|c|}
\hline Factors effecting the business value & $\begin{array}{l}\bar{D} \\
0 \\
D \\
0 \\
\Xi \\
0 \\
0 \\
0 \\
0 \\
0 \\
0 \\
0 \\
z \\
z\end{array}$ & 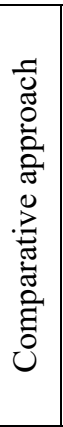 & 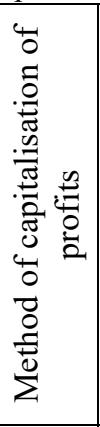 & 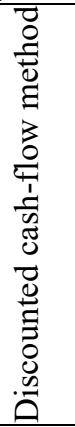 & $\underset{\amalg}{\mathbb{Z}}$ & $\underset{\sim}{\mathbb{s}}$ & $\underline{\simeq}$ & $\begin{array}{l}\bar{O} \\
\widetilde{x} \\
\underline{U}\end{array}$ & 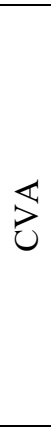 \\
\hline 1. Sales revenue & + & + & + & + & + & + & + & + & + \\
\hline 2. Unit price & + & + & + & + & + & + & + & + & + \\
\hline 3. Unit cost & + & + & + & + & + & + & + & + & + \\
\hline 4. Fixed costs of production & + & + & + & + & + & + & + & + & + \\
\hline 5. Business and management expenses & + & + & + & + & + & + & + & + & + \\
\hline 6. Other income and expenses & + & + & + & + & - & - & + & - & \\
\hline 7. Amount of debt $*$ & + & + & + & $+/-$ & + & + & + & - & + \\
\hline 8. Amount of internal capital * & + & + & - & $+/-$ & + & + & + & + & + \\
\hline 9. Cost of debt $*$ & + & + & + & $+/-$ & + & + & + & - & + \\
\hline 10. Equity cost of capital & - & - & - & + & + & + & + & - & + \\
\hline 11. Rate of income tax & + & + & + & + & + & + & + & + & + \\
\hline 12. Distributed dividends & + & + & - & - & - & - & - & - & - \\
\hline $\begin{array}{l}\text { 13. Additional instalments to equity } \\
\text { capital of the company }\end{array}$ & + & - & - & - & - & - & - & - & - \\
\hline 14. Depreciation charge $* *$ & \begin{tabular}{c|}
$+/$ \\
-
\end{tabular} & + & $+/-$ & + & \begin{tabular}{c|}
$+/$ \\
-
\end{tabular} & $\begin{array}{l}+1 \\
-\end{array}$ & $\begin{array}{l}+1 \\
-\end{array}$ & + & + \\
\hline 15. Asset acquisition value $* *$ & \begin{tabular}{c|c}
$+/$ \\
-
\end{tabular} & + & $+/-$ & + & \begin{tabular}{c|c}
$+/$ \\
-
\end{tabular} & $\begin{array}{ll}+1 \\
-\end{array}$ & $\begin{array}{ll}+1 \\
-\end{array}$ & + & + \\
\hline $\begin{array}{l}\text { 16. Value and structure of operating } \\
\text { assets }\end{array}$ & - & + & - & + & + & + & + & - & - \\
\hline 17. Value of current liabilities & - & + & - & + & + & + & + & - & - \\
\hline $\begin{array}{l}\text { 18. Value and structure of non- } \\
\text { current assets }\end{array}$ & - & + & - & + & + & + & + & - & - \\
\hline 19. Value of long-term liability & - & + & - & + & + & + & + & - & - \\
\hline
\end{tabular}

* "+//" - at discounting of cash flow by invested capital;

$* *$ " +/_" - taken into account indirectly at net profit assessment.

The value-based management organization of the company is a functionality of administration, enterprise, therefore the provided indicators are internal factors generating 
the upper-level value. A universal corporate value management applicable to any business without adjustments can't be developed, for every company is unique with their own accounting policy, corporate structure and industry-related specifics. Therefore, the next stage is conduction of analysis of susceptibility of business to presented factors in terms of current economic operations of individual company in order to identify the most essential benchmarks with primary impact on increase of business value.

The final stage is further decomposition of selected indicators to medium and lower management level enablers (development of regulations, instructions, process charts for staff etc.) containing key requirements to work, job profiles and standard processes at the company, whose implementation will ensure increase of the business value all the way from the lay workers up to the highest levels of management.

\section{References}

1. D.L. Volkov, The Russian Management Journal, 3(2), 3-42 (2005)

2. A.V. Dushin, V.A. Taktashkin, Economy of the Region, 1, 88-95 (2013)

3. A.L. Loginov, Business value management as a tool increasing the company's competitive power, Competitive power of economic operators in conditions of emerging environmental challenges: problems and ways to their solution. Proceedings of the $X X$ International research and practice conference, 116-132 (2017)

4. A.L. Loginov, N.V. Maltsev, A.N. Syomin, Economy of the Russian agriculture, 9, 2-11 (2019)

5. A.K. Solodov, Financial manager, 3, 22-39 (2013)

6. O.N. Shcherbakova, Financial management, 3, 46-54 (2003)

7. A. Ohlson James, Contemporary Ac-counting Research, 11, 661-687 (1995)

8. A. Rappaport, Creating shareholder value: a guide for managers and investors, 205 (New York: Free Press, 1998) 